\title{
Article \\ Assessment of the Impact of Coaching on a Company's Performance: A Review of Methods
}

\author{
Angelina Roša (Rosha) *(D) and Natalja Lace (D) \\ Faculty of Engineering Economics and Management, Riga Technical University, 6 Kalnciema Str., \\ LV-1048 Riga, Latvia; Natalja.Lace@rtu.lv \\ * Correspondence: angelina.rosa@rtu.lv
}

\section{check for} updates

Citation: Roša, A.; Lace, N. Assessment of the Impact of Coaching on a Company's Performance: A Review of Methods. J. Open Innov. Technol. Mark. Complex. 2021, 7, 233. https://doi.org/10.3390/joitmc7040233

Received: 23 July 2021

Accepted: 5 November 2021

Published: 1 December 2021

Publisher's Note: MDPI stays neutral with regard to jurisdictional claims in published maps and institutional affiliations.

Copyright: (c) 2021 by the authors. Licensee MDPI, Basel, Switzerland. This article is an open access article distributed under the terms and conditions of the Creative Commons Attribution (CC BY) license (https:// creativecommons.org/licenses/by/ $4.0 /)$.

\begin{abstract}
The aim of the present study is to provide an analysis of the literature about methods for assessing the impact of coaching on the performance of a company, and elaborate a framework of assessment methods emphasizing their use in the course of coaching interaction. The paper also explores the relationship between open innovation and coaching and proposes the themes for further research. The Scopus and Web of Science databases were selected for the review of the research papers in the business subject area. The review was guided by the following research questions: What methods are used for assessing the impact of coaching? How are these methods used in the course of the coaching interaction? How does coaching interrelate with open innovation? The findings suggest that the assessment of the impact of coaching on the individual's behavior and performance of a company is considered from different perspectives. The methods differ based on the needs for the assessment whether the process evaluation or the outcome evaluation is required. The analysis of the literature proves that the relationship between coaching and open innovation is mutually advantageous.
\end{abstract}

Keywords: coaching; open innovation; impact; methods for assessment; company's performance

\section{Introduction}

Nowadays, companies are compelled to conduct their business and innovate in a dynamic, complex environment, struggling with circumstances that have catastrophic effects [1]. Yusr [2] suggests that when companies seek to achieve a competitive advantage through innovation, they need to make more efforts in building their innovation capability. Support for sustainable innovation performance has become a subject of critical consideration only over the past twenty years. A group of scientists [3] conducted the research and concluded that for achieving sustainable performance, an organization should supplement its technical and innovative capabilities with practices that support the employees who develop and apply the sustainable processes.

Coaching is the process for facilitating individuals' self-directed learning driven by a coach who triggers the individuals' knowledge creation and transformation of experience for achieving their goals through disclosing their potential and enhancing awareness of new opportunities. For the needs of a company, coaching is mostly used in management development, leadership development and human resource development. The scientific literature on coaching provides a large amount of evidence about the impact of coaching on the development of leadership and managerial skills [4]. A group of scholars [5] compared the impact of executive coaching as management competency training and development strategy with other methods that are used for training and development of managers. The results confirmed that executive coaching had more impact on changes in the behavior of managers than attendance-based executive training courses.

The existing reviews of the scientific literature in the field of coaching focus on such aspects as qualitative studies of executive and workplace coaching [6], and the determinants of the effectiveness of workplace coaching [7]. However, an initial exploration of the 
available scientific literature revealed the shortage of reviews on the assessment methods aimed at estimating the impact of coaching on a company's performance which is believed to have changed as a result of the coaching interactions. Moreover, this issue is particularly topical for companies that have invested in coaching and want to gain insight into how coaching interactions have influenced the company's performance, to be sure that coaching really brings to visible positive growth of final outcomes. Meanwhile, companies face challenges related to measuring the impact of coaching, it still remains unclear for them if a true impact of coaching can be measured.

Therefore, to bridge a gap between the existing and desired state of research, this paper provides an analysis of the methods which are used to assess the impact of coaching on the company's outcomes, and, based on it, elaborates a coherent framework of assessment methods which are considered in the literature in recent years. The paper also explores the relationship between open innovation and coaching and proposes the themes for further research.

First, the review of the available literature covers the topics which are significant for the present study, namely a gradual impact of coaching, the impact of coaching on open innovation processes in a company, and the assessment of the impact of coaching. Second, the paper describes the methodology for the systematic literature selection process for further analysis, then, the findings of the literature analysis are systemized and the research agenda is recommended. Finally, the implementation of the results for research and practice is discussed.

\section{Literature Review}

\subsection{Gradual Impact of Coaching}

Coaching occupies a steady position among development practices in business [8]. Researchers and coaching practitioners provide direct evidence of the long-run impact of coaching not only on the individual's behavior but also on the organization's improvements in productivity [8].

Coaching promotes behavioral changes which, in a chain of impact, lead to substantial business results. The extensive experience of a group of scholars [8] has led to a growing understanding of the gradual impact of coaching. From their perspective, coaching interactions have resulted in the improvement of individual performance, which in turn translates into positive changes at the organizational level, and above all, the scholars highlight that this impact of coaching can be measured.

The literature explains in which way coaching can facilitate behavioral change. Coaching increases self-awareness and improves self-directed learning, which enables individuals to view the business opportunities from different perspectives and take timely decisions $[9,10]$. The analysis of the scientific literature shows that the gradual impact of coaching primarily occurs in the areas related to development, such as management development, leadership development, and human resource development. Scholars have provided evidence that coaching improves leadership skills through providing feedback and reflection which enhance the capacity of critical thinking of managers and executives $[9,11]$. Coaching fosters the development of entrepreneurial skills, contributing to the implementation of own strategic vision of the key players of a company [12].

It should be noted that the gradual impact of coaching can manifest itself not only in day-to-day activities, but coaching is a valuable practice for facilitating innovation processes in a company.

\subsection{The Impact of Coaching on Open Innovation Processes in a Company}

Nowadays, a company's high performance is closely related to its capability to initiate and maintain innovation. Contemporary business attaches particular importance to open innovation. Not only multinational corporations but an increasing number of small and medium enterprises (SMEs) are engaged in the open innovation process [13]. The empirical findings, provided by Parida, Westerberg and Frishammar [14], supported the proposition 
that inbound open innovation activities advance innovation performance of small and medium enterprises.

Open innovation is defined as "... the use of purposive inflows and outflows of knowledge to accelerate internal innovation ... " [15]. Cross-border inflows and outflows of technologies, knowledge, and ideas are considered as a core of open innovation.

While open innovation is widespread in the current business environment, the perception of the open innovation phenomenon is possible only when companies understand the dynamic processes of specific open innovation strategies [16]. Whittington, Cailluet and Yakis-Douglas [17] state that open innovation strategies are "a subset of open strategy: innovation is just one of many kinds of strategy process increasingly subject to openness" [17].

Academic studies highlight the following key processes which are incorporated in the open innovation paradigm:

- Engaging external knowledge into internal innovation activities;

- The use of networks when commercializing the innovation outcomes;

- Intellectual property protection $[15,18]$.

At the same time, innovation processes in business are the subject of intense debate among scholars. Opposed to the linear pipeline models of innovation, Berkhout, Hartmann and Trott [19] proposed a cyclic innovation model which provides "a cross-disciplinary view of change processes (and their interactions) as they occur in an open innovation arena" [19]. The model consolidates behavior sciences, engineering, natural sciences and markets into a coherent system of circular processes with four principal nods. Entrepreneurship is placed at the center of the model, thereby emphasizing the dynamic interdependency of business and innovation. "The message is that without the drive of entrepreneurs there is no innovation, and without innovation there is no new business" [19].

Traditionally, the research to study the open innovation concept is associated with the investigation of the company's innovation performance at the organizational level. However, recently, there was a shift towards research of open innovation at a micro(individual) level $[20,21]$. Meanwhile, there is also a view that both levels are vital for the research on the high innovation performance of a company [18,22].

To attain innovation goals, the company needs to develop innovation capabilities that can be boosted by an innovation-oriented organizational culture, characterized by the acceptance and adoption of inbound knowledge flows and outside know-how, this culture is manifested in the appropriate behavior and attitude of individuals to novelty $[18,22]$.

Behavior and performance are connected with the individual's way of thinking. Scholars highlight the importance of the concept of mindset in open innovation $[20,23]$. Open innovation mindset is defined as "... an individual's values, attitudes, and beliefs that capture an individual's openness ... " [20] towards knowledge sourcing and sharing. The researchers emphasize that open innovation mindset is crucial for making innovation decisions [20]. A shared mental model is also critical for effective collaboration between numerous parties involved in the innovation process [19]. A group of scholars [24] explored the elements which underpin the mindset of entrepreneurs who are dedicated to open innovation ideas. They concluded that open innovation mindset means openness, building mutual trust, risk-taking and adaptability to change. A positive attitude toward openness is regarded as a favorable factor for successful open innovation [16,25]. The findings of the research conducted by Engelsberger with a group of scholars [20] evidenced that companies should invest in practices which facilitate developing open innovation mindset among employees. Coaching, along with selective recruitment and training, was identified as the practice that can reduce uncertainty and increase collaboration, thereby fostering the creation of an environment which encourages the development of open innovation mindset [20]. The scientific literature provides a number of examples that demonstrate the use of coaching for improving the way of thinking to increase innovation capabilities of individuals, and thus enhance the innovation performance of a company [26].

Open innovation requires not only intra-organizational relations to sustain and support internal innovation, but also a collaboration between the company and other or- 
ganizations engaged in the innovation process to provide knowledge flows across the boundaries. In this context, to be successful, the innovation process should be supported by the leaders who promote innovative ideas and maintain cooperation across functional and organizational boundaries [27]. Viewed from this angle, the role of leaders takes on a new dimension, which requires new knowledge and skills acquisition. Open innovation is also referred to as "network innovation" [28], so the qualities, such as openness, a strong desire to know and learn new things, willingness to accept external ideas and discoveries, have become key features of innovation leaders. The scientific literature proves that coaching promotes the development and improvement of the qualities and skills of leaders which contributes to the creation and maintenance of an innovative culture and thereby accelerates innovation processes in a company [29].

The development of entrepreneurial skills is critical for the creation of an innovation culture in a company. The scientific literature provides examples of how coaching specialists, i.e., personal coaches of corporate incubators, facilitate improving entrepreneurial knowledge by supporting the employees throughout the stages of the open innovation process: from establishing an open innovation flow to commercializing a new product or technology [30]. Coaching is suggested to be used in the corporate incubators to encourage a range of innovation activities, such as idea-generating, experimenting with potential markets, exploring prospective partnerships, etc. For these purposes, coaching triggers the problem-solving process to promote the "commercial self-sufficiency" of business [31].

Building a favorable climate for innovation contributes to the development of the innovation capability of a company. High innovation capability provides an opportunity for a company to transform external knowledge into internal intellectual assets and thereby contributing to long-run sustainable growth [32]. The scientists agree that coaching facilitates creating an innovation environment by inspiring the leaders and the individuals engaged in the innovation process to refine the innovative ideas, modify them into a sustainable course of actions and thereby convert inventions into innovations [11,22,33-35]. There is evidence that in the process of the formation of new innovation ideas, coaching, along with feedback, is used as one of the practices aimed at discovering new opportunities and accelerating the transformation of ideas into innovation [36].

Although the external knowledge flows are considered as a fundamental point of open innovation, internal sources in the form of knowledge, structure and processes enable a company to utilize external sources and integrate them with internal flows of knowledge, thus improving the company's innovation capability [37]. One of the internal sources of knowledge is employees, therefore it is important to encourage employees to be proactive in the innovation process. Coaching, together with team learning, peer support and performance review, facilitates employees to express and promote their ideas [38]. Whittington, Cailluet and Yakis-Douglas [17] view coaching, as a practice that can replace one-way advice by empowering employees to think, act and achieve.

Commercialization is a decisive stage in the innovation process. In the view of several scholars [39], there is no one best way to bring innovation to the market. Commercial success depends on internally coordinated strategic and tactical commercialization decisions aimed at encouraging positive attitudes and gaining support for dissemination of innovations in the market. Commercializing innovations is coupled with collaboration between the company and external stakeholders [40]. The research conducted by Gassmann, Daiber and Enkel [41] shed light on the role of external institutions (intermediary) which support and assist companies in their innovation-based activities: from recognizing the value of external knowledge to commercializing innovation. The scholars concluded that coaching provided by an intermediary can be applied in the period of integration of a new product into the customer's company. For this purpose, coaching is in the same line as product development support [41].

The consolidated Table 1 summarizes the findings made in the scientific literature which provide evidence of the impact of coaching on the open innovation performance of a company. 
Table 1. The impact of coaching on the processes in open innovation.

\begin{tabular}{|c|c|c|}
\hline Open Innovation Processes & $\begin{array}{c}\text { The Fields Where Coaching Can } \\
\text { Be Applied }\end{array}$ & How Coaching Can Impact \\
\hline The entire open innovation process & $\begin{array}{l}\text { Facilitate improving entrepreneurial } \\
\text { knowledge and skills }\end{array}$ & Strengthening innovation culture \\
\hline External knowledge sourcing & $\begin{array}{l}\text { Cooperation across company's } \\
\text { boundaries }\end{array}$ & $\begin{array}{l}\text { Improves collaboration between a } \\
\text { company and external agents }\end{array}$ \\
\hline $\begin{array}{l}\text { Experimenting with potential markets, } \\
\text { and exploring prospective partnerships }\end{array}$ & $\begin{array}{l}\text { Developing open innovation mindset and } \\
\text { building shared mental model }\end{array}$ & $\begin{array}{l}\text { Reducing uncertainty, increasing mutual } \\
\text { trust and promoting positive attitude } \\
\text { to change }\end{array}$ \\
\hline Leading innovation & $\begin{array}{l}\text { Developing and supporting } \\
\text { open-innovation-oriented qualities and } \\
\text { skills of the leaders }\end{array}$ & $\begin{array}{l}\text { Leaders recognize the value of listening } \\
\text { and considering new ideas }\end{array}$ \\
\hline Generating and refining innovation ideas & Creating innovation environment & $\begin{array}{l}\text { Advancing the processes of converting } \\
\text { innovative ideas into real innovation } \\
\text { projects }\end{array}$ \\
\hline $\begin{array}{l}\text { Utilizing and integrating external and } \\
\text { internal sources }\end{array}$ & $\begin{array}{l}\text { Fostering proactive approach to } \\
\text { innovation activities }\end{array}$ & $\begin{array}{l}\text { Employees recognize innovation } \\
\text { opportunities and put forward their } \\
\text { proposals }\end{array}$ \\
\hline Commercializing innovation & $\begin{array}{l}\text { Support in integrating a new product into } \\
\text { the customer's company }\end{array}$ & $\begin{array}{l}\text { Self-directed learning to get knowledge } \\
\text { about new products is increased }\end{array}$ \\
\hline
\end{tabular}

In view of the above, it can be concluded that coaching can have a positive impact on the processes occurring in a company at the time of open innovation activities. It is also important to note that coaching not only entails the improvement of the internal innovation environment, making it more open and inclusive, but coaching also facilitates the company to strengthen collaboration with external parties involved in innovation, thereby increasing the amount of inbound and outbound knowledge flows.

\subsection{Assessing the Impact of Coaching}

Scholars and coaching practitioners agree regarding the importance of assessing the impact of coaching, however, they lack consensus on the methods to be applied for the assessment of the process and outcomes of coaching. A group of scientists advocates for estimating the economic return on investments (ROI) as outcomes of coaching [8,42]. At the same time, another group of scientists promotes the methodology which assesses qualitative aspects as opposed to quantitative methods. The proponents of qualitative assessment methods argue that these methods can provide stronger evidence in estimating the improvements of an individual's self-development as well as the enhancement of management skills owing to coaching interactions [43-45]. There is also a point of view that the assessment of impact is to undergo throughout the entire process of coaching interaction and combine both qualitative and quantitative methods of assessment [46].

The impact of coaching is evaluated in different ways, including measuring the degree of satisfaction of coaching clients with coaching interactions, determining the achievement of established goals, evaluating behavior change due to coaching interaction, assessing the impact of coaching at the organizational level. This variety is partly due to the fact that scholars and practitioners have different views on how coaching should be assessed [43].

At the same time, scholars and practitioners acknowledge that a structured and systematic approach to the assessment of the impact of coaching can considerably increase the reliability of estimates. From the scholars' point of view, the assessment of the impact of coaching should be targeted in particular towards (1) the process, this provides an opportunity to assess the ongoing impact of coaching interaction on the achievement of goals; and (2) the outcomes to estimate the final results of a completed coaching interaction [43]. 
The following principles crucial for assessing the impact of coaching were identified by the scholars [43]:

1. The integration of the evaluation of ongoing coaching activities towards achieving the established goals with the assessment of the outcomes of a completed interaction.

2. The establishment of clear criteria (ROI vs. coaching objectives) against which to assess the impact of coaching interactions on a company's performance.

3. Ensuring that the assessment of the impact is carried out with sufficient accuracy. It is recognized that the use of a pre-post design to assess the impact and the establishment of a control group can increase the rigor of the estimation of the impact of coaching. 4. Considering the needs of coaching clients and organizations which can be met by coaching.

Therefore, the assessment of the impact of coaching and demonstration of its effect still remains an underexplored field of study $[8,43,47]$. Moreover, so far companies face a dilemma of how to assess the impact of coaching on their performance.

\section{Materials and Methods}

The study adopted the systematic literature review approach to provide a deeper understanding of what evidence is available about the assessment methods to evaluate the impact of coaching. The supplementary literature search was provided to find out how the scientific texts reflect the relationship between coaching and open innovation, and specifically what topics are discussed regarding the impact of coaching on innovation activities of a company.

The search process was initiated with formulation of the research questions:

1. What methods are used for assessing the impact of coaching?

2. How are these methods used in the course of the coaching interaction?

3. How does coaching interrelate with open innovation?

To answer research questions 1 and 2, Scopus and Web of Science databases with broad access to peer-reviewed literature related to the research questions were selected for investigation.

To be included in the review, the article has to meet the following requirements: (1) the article has to study the application of the assessment methods within the business context; (2) the time span of the literature is between 2000 and 2020 since the majority of the papers and a large number of new trends emerged during this period. (3) only studies published in English are included in the review.

To identify the largest possible number of relevant papers, Boolean operators and truncation were used. This allowed combining different search queries as well as identifying the relevant studies that have variants of the search terms. Eventually, the search formula used was:

Coaching AND (impact OR outcomes OR results OR effect*) AND (assess* OR evaluat* OR measur*). The search strings were addressed to article titles, abstracts, and keywords.

The initial article search based on the inclusion criteria produced 409 potentially relevant papers in Scopus and Web of Science databases in total. In the second stage of the literature selection process, 409 were screened by title, keywords and abstract. A total of 356 articles were excluded based on title, keywords and abstract because it turns out that they were not empirical papers, the papers were not exactly addressed to business context. In the third stage, 53 accepted papers were scanned, the articles that failed to meet the inclusion criteria were excluded. A total of 40 articles were excluded based on full-text review because the papers did not specify the assessment methods or because the context was on the impact of coaching but not within a company. After the full-text examination, the number of relevant articles was reduced to 13. After validating the inclusion, exclusion and quality criteria against extracted studies, the final sample comprises 13 papers.

The selected studies were coded in order to provide a comprehensive review of the literature. Then the articles were analyzed according to the themes identified for further 
analysis. The process is resulted in elaborating a framework of the methods used for assessing the impact of coaching.

To answer research question 3, which is related to the relationship between coaching and open innovation, the literature search was expanded. The search in Scopus and Web of Science databases was supplemented by the search in Google Scholar. This was due to the fact that the availability of scientific literature which investigates the relationship between coaching and open innovation is limited. The search terms "open innovation" and "coaching" were used. The search strings were aimed at article titles, abstracts and keywords. To be included in the review, the article has to study open innovation and coaching in business context. Only studies published in English are included in the review.

The initial search in Scopus produced eight documents. The articles related to Computer Science, Mathematics, Energy and Engineering were excluded from the list. As a result, only two documents were selected for full paper review. However, one of the two papers was excluded, because it was a conference introductory article. The second paper might be of interest to the analysis, but only abstract was available in Scopus and other databases. Therefore, it was decided to select this article for general consideration.

The search in Web of Science returned 48 results. Only articles that are related to Business and Economics research areas were selected for the further procedure. Due to this, seven articles were scanned to evaluate their accordance which research question 3 , and only one article was selected for further analysis.

The search in Google Scholar produced five relevant articles. Scanning the reference list of the selected articles did not produce any results. Therefore, six available scientific articles were selected to explore the literature on open innovation and coaching in Business and Economics subject areas.

\section{Results and Discussion}

\subsection{Methods for Assessing the Impact of Coaching}

Based on the systematic literature search, the following papers were selected for the further analysis of the methods which are currently used to assess the impact of coaching on the performance of a company: Birknerová, Z. and Benková, E. [48]; Albizu, E., Rekaldee, I., Landeta, J., Fernández-Ferrín, P. [49]; Wenu, A. and Tan, C. [50]; Pousa, C., Hardie, T., Zhang, X. [51]; Hagen, M.S. and Peterson, S.L. [52]; Nansubuga, F., Munene, J.C., Ntayi, J.M. [53]; Gan, G.C., Chong, C.W. [54]; Grant, A.M. [55]; Vidal-Salazar, M.D., Ferrón-Vílchez, V., Cordón-Pozo, E. [56]; Gray, D.E., Ekinci, Y., Goregaokar, H. [57]; Jones, R.A., Rafferty, A.E., Griffin, M.A. [58]; Boak, G., Crabbe, S. [59]; Nguyen C.A., Artis, A., Plank, R., Solomon, P. [60].

Table 2 provides information to answer research question 1, about the assessment methods which were used to evaluate the impact of coaching and what place the assessment methods take in the context of the overall research reported in the paper.

All selected articles are research papers. Most of the papers [49,51,53,55,56,58,59] describe the use of the assessment methods in the context of testing the impact of coaching on individuals' and company's performance. Papers $[48,60]$ describe the development of new assessment methods and tools. Paper [52] tests the existing measuring tools. Papers $[50,54,57]$ have different goals of the research, and the assessment is included as an integral part.

The analysis of the papers enables us to identify the key methods for measuring the impact of coaching as well as the ways of application of the assessment methods.

Birknerová, Z. and Benková, E. [48] developed a new methodology for assessing the impact of coaching on an individual's behavior, emotions and cognitions provided by trade managers who received coaching. The assessment of the factor "behavior" is focused on the evaluation of the use of the experience gained from coaching. The factor "emotions" is related to the assessment of the individual's perception of coaching interaction. The factor "cognitions" evaluates the individual's readiness to increase self-awareness and make positive changes. 
Table 2. The analysis of the papers selected for the literature review.

\begin{tabular}{|c|c|c|c|c|}
\hline & Author & Aim of the Paper & Assessment Methods & Application of Methods \\
\hline 1 & Birknerová and Benková [48] & $\begin{array}{l}\text { to develop a methodology for } \\
\text { assessing the factors of coaching by } \\
\text { coaching recipients }\end{array}$ & AC-BEC methodology & $\begin{array}{l}\text { developed to assess the } \\
\text { coaching factors }\end{array}$ \\
\hline 2 & Albizu et al. [49] & $\begin{array}{l}\text { to provide an empirical test of } \\
\text { effectiveness of executive coaching }\end{array}$ & $\begin{array}{l}\text { first three levels of Kirkpatrick's } \\
\text { evaluation model (1975). }\end{array}$ & as a tool for summative evaluation \\
\hline 3 & Wenu and Tan [50] & $\begin{array}{l}\text { to elaborate the project management } \\
\text { coaching framework }\end{array}$ & $\begin{array}{l}\text { Kirkpatrick and Kirkpatrick's (2016) } \\
\text { learning model }\end{array}$ & $\begin{array}{l}\text { as a means to evaluate the validity of } \\
\text { the AKW-PMCF framework developed }\end{array}$ \\
\hline 4 & Pousa et al. [51] & $\begin{array}{l}\text { to explore the impact of managerial } \\
\text { coaching on employees' performance }\end{array}$ & $\begin{array}{l}\text { survey questionnaire with subsequent } \\
\text { data processing through structural } \\
\text { equation modeling in AMOS }\end{array}$ & $\begin{array}{l}\text { as an assessment of the impact of } \\
\text { coaching interaction }\end{array}$ \\
\hline 5 & Hagen and Peterson [52] & $\begin{array}{l}\text { to test the exciting coaching scales for } \\
\text { reliability and validity to measure } \\
\text { managerial coaching experience }\end{array}$ & $\begin{array}{l}\text { Ellinger Behavioral Scale and the Park } \\
\text { Skills-based Scale }\end{array}$ & $\begin{array}{l}\text { Ellinger Behavioral Scale is proposed } \\
\text { to use for team members while the } \\
\text { Park Skills-based Scale for leaders }\end{array}$ \\
\hline 6 & Nansubuga et al. [53] & $\begin{array}{l}\text { to assess the effect size of coaching } \\
\text { interaction regarding the ability to } \\
\text { coach clients to reflect on their behavior }\end{array}$ & $\begin{array}{l}\text { pre-test assessment, treatment group } \\
\text { and control groups, and post-test } \\
\text { assessment }\end{array}$ & $\begin{array}{l}\text { as an assessment of the entire chain of } \\
\text { impact of coaching interaction }\end{array}$ \\
\hline 7 & Gan and Chong [54] & $\begin{array}{l}\text { to research the relationship of trust, } \\
\text { rapport and commitment with the } \\
\text { effectiveness of coaching }\end{array}$ & objective-driven model & $\begin{array}{l}\text { as the measurement of coaching goals } \\
\text { achievement }\end{array}$ \\
\hline 8 & Grant [55] & $\begin{array}{l}\text { to assess the impact of coaching at the } \\
\text { time of organizational change }\end{array}$ & $\begin{array}{l}\text { a set of qualitative and quantitative } \\
\text { methods of evaluation: } \\
\text { pre-/post- design }\end{array}$ & $\begin{array}{l}\text { measures were taken at Time } 1 \text { (pre) } \\
\text { and Time } 2 \text { (four months later) }\end{array}$ \\
\hline 9 & Vidal-Salazar et al. [56] & $\begin{array}{l}\text { to investigate the effect of coaching } \\
\text { interaction in the course of the } \\
\text { management development program }\end{array}$ & $\begin{array}{l}\text { coached group vs. control } \\
\text { (non-coached) group }\end{array}$ & $\begin{array}{l}\text { as an assessment of complementary } \\
\text { effect of coaching in the } \\
\text { development program }\end{array}$ \\
\hline 10 & Gray et al. [57] & $\begin{array}{l}\text { to identify favorable factors of } \\
\text { coaching interaction in SMEs }\end{array}$ & $\begin{array}{l}\text { survey developed grounded on a range } \\
\text { of management competencies. }\end{array}$ & $\begin{array}{l}\text { as a tool to assess the impact of } \\
\text { coaching on personal traits and } \\
\text { business-oriented attributes }\end{array}$ \\
\hline 11 & Jones et al. [58] & $\begin{array}{l}\text { to identify the impact of coaching on } \\
\text { managerial flexibility. }\end{array}$ & repeated-measures design & $\begin{array}{l}\text { to take measures over the entire } \\
\text { coaching interaction including pre- and } \\
\text { post-stages }\end{array}$ \\
\hline 12 & Boak and Crabbe [59] & $\begin{array}{l}\text { to assess the impact of coaching } \\
\text { training skills program }\end{array}$ & $\begin{array}{l}\text { ongoing feedback, focus group, } \\
\text { post-program one-to-one interviews }\end{array}$ & $\begin{array}{l}\text { to collect data about the impact } \\
\text { of coaching }\end{array}$ \\
\hline 13 & Nguyen et al. [60] & $\begin{array}{l}\text { to develop and validate sales coaching } \\
\text { scale to measure the effectiveness of } \\
\text { sales coaching }\end{array}$ & $\begin{array}{l}\text { a three-factor, } 14 \text {-item effective sales } \\
\text { coaching (ESC) scale }\end{array}$ & $\begin{array}{l}\text { to measure adaptability, involvement, } \\
\text { and rapport }\end{array}$ \\
\hline
\end{tabular}

A group of researchers (Albizu et al. [49]) applied the first three levels of Kirkpatrick's evaluation model (1975) to estimate the effectiveness of executive coaching. The assessment of coaching factors was from a coachee perspective. The authors conclude that despite criticism of Kirkpatrick's model, it seems appropriate to consider utilizing the model for summative evaluation of coaching to identify the coachee's learning and development changes.

Wenu, A. and Tan, C. [50] elaborated an "applied, knowledge, work-based project management coaching framework" (AKW-PMCF). Kirkpatrick and Kirkpatrick's (2016) learning model was used to evaluate the effectiveness of the coaching programs to provide evidence of the feasibility and utility of the AKW-PMCF framework.

The paper of scholars (Pousa et al. [51]) reports on the study where a traditional method of assessment, namely questionnaire, was applied to evaluate the impact of coaching received by frontline employees of a large insurance company in China. The measures were targeted to estimate the influence of managerial coaching on employees' customer and sales orientation, and their performance. The data obtained were analyzed by using structural equation modeling in AMOS.

The study conducted by Hagen and Peterson [52] was aimed to measure the reliability and validity of two existing coaching scales-the Ellinger Behavioral Scale and the Park Skills-based Scale- to find out the extent to which management coaching skills, i.e., a behavioral construct and skill-based construct, are precisely measured. The authors suggested applying the Ellinger Behavioral Scale for team members and the Park Skills-based Scale for leaders.

Nansubuga, Munene and Ntay [53] applied a quasi-experimental non-equivalent group design which involves a baseline assessment of participants' ability to reflect on 
their actions, treatment group and control groups, and post-test assessment to estimate effect size caused by coaching.

The research, carried out by Gan and Chong [54], was aimed to investigate the alignment between three key components of the coaching relationship, namely rapport, trust and commitment, and coaching effectiveness. The method of data collection was a survey questionnaire, and an objective-driven model was used to measure the effectiveness of executive coaching, in other words, the extent of the achievement of coaching goals.

Grant [55], in his study concerning the exploration of the impact of executive coaching at the time of organizational change, applied both qualitative and quantitative methods of measuring. The methods, among which Goal Attainment Scaling (GAS) and SolutionFocused Inventory (SFI), were intended to evaluate the attainment of work-related goals which were aligned with the purpose of the coaching program, and to assess changes in solution-focused thinking.

The use of a control group is considered a reliable way to make measurements through a comparison of the performance of the coached and control groups. Various researchers apply this method differently. In some cases, the control group is assigned over the entire period of coaching interaction, as it was designed in the research conducted by Nansubuga, Munene and Ntay [53]. While in the other cases, the control group is designed at the final stage of the development program. The last one is applied by Vidal-Salazar, Ferrón-Vílchez and Cordón-Pozo, E. [56]. The scholars conducted the research to study the effectiveness of coaching in the course of the management development program. The participants were divided into two groups. One of these groups received coaching as a complement to the program, and the differences between the groups were identified.

Gray, Ekinci and Goregaokar [57] developed a survey tool to evaluate the impact of executive coaching on the performance of small- and medium-sized enterprises. The specific feature of the method was the use of a range of relevant management competencies derived from the occupational standards as a background. The results of the survey were analyzed through performance importance analysis which originally was applied in the marketing sector to evaluate customer satisfaction.

Jones, Rafferty and Griffin [58] conducted the study to identify the impact of coaching on managerial flexibility. They applied a repeated measures design to make assessments prior to coaching interaction, during coaching and post-coaching.

Boak and Crabbe [59] evaluated the impact of coaching on individual and organizational performance. The information on the effect of the coaching program was gathered through ongoing feedback, focus group and one-to-one interviews following the completion of the program.

Nguyen, Artis, Plank, and Solomon [60] developed and validated a three-factor, 14-item effective sales coaching (ESC) scale to identify the direct and indirect influence of coaching interaction on the performance of sales staff.

The analysis of the selected papers has led to the conceptualization of the methods which are actually being used to assess the diverse impact of coaching interaction. Table 3 presents the framework for the assessment methods and answers research question 2 of how the methods are used in the course of the coaching interaction.

As it became evident, both traditional methods, among which survey questionnaires, control groups, interviews, as well as newly developed tools, such as new coaching scales, are used to assess the impact of coaching. This reflects a common trend which is advocated in recent years by scholars. Gil Bozer and Rebecca J. Jones [61] put forward a comprehensive agenda to strengthen the research in coaching in the organizational context. They highlight the need to measure coaching outcomes from multiple data sources and broaden the range of objective datasets. 
Table 3. The framework of the methods for assessing the impact of coaching.

\begin{tabular}{|c|c|c|}
\hline Methods & The Use in the Course of the Coaching Interaction & Study \\
\hline \multicolumn{3}{|c|}{ Singly Applied Methods } \\
\hline \multirow{3}{*}{$\begin{array}{l}\text { Survey questionnaire data were } \\
\text { analyzed }\end{array}$} & using structural equation modeling in AMOS & Pousa et al. [51] \\
\hline & $\begin{array}{l}\text { objective-driven model to evaluate the extent to which } \\
\text { coaching objectives were met. }\end{array}$ & Gan and Chong [54] \\
\hline & using importance-performance analysis & Gray et al. [57] \\
\hline Coached group vs. control group & $\begin{array}{l}\text { the data obtained as a result of comparing the } \\
\text { performance of the groups were analyzed through the } \\
\text { Wilcoxon-Mann-Whitney test }\end{array}$ & Vidal-Salazar et al. [56] \\
\hline $\begin{array}{l}\text { Managerial coaching scales: the } \\
\text { Ellinger Behavioral Scale and the } \\
\text { Park Skills-based Scale }\end{array}$ & $\begin{array}{l}\text { to measure managerial coaching skills and } \\
\text { coaching experience }\end{array}$ & Hagen and Peterson [52] \\
\hline $\begin{array}{l}\text { A three-factor, } 14 \text {-item effective } \\
\text { sales coaching (ESC) scale }\end{array}$ & $\begin{array}{c}\text { contains three dimensions-adaptability, involvement, } \\
\text { and rapport-that are shown to directly and indirectly } \\
\text { influence sales performance. }\end{array}$ & Nguyen et al. [60] \\
\hline AC-BEC methodology & $\begin{array}{l}\text { the assessment of coaching from the point of view of } \\
\text { behavior, emotions, and cognition, using } \\
\text { mathematical-statistical methods. }\end{array}$ & Birknerová and Benková [48] \\
\hline \multirow[t]{2}{*}{ Kirkpatrick's learning model } & $\begin{array}{l}\text { first three levels of Kirkpatrick's evaluation } \\
\text { model (1975). }\end{array}$ & Albizu et al. [49] \\
\hline & Kirkpatrick and Kirkpatrick's (2016) learning model & Wenu and Tan [50] \\
\hline \multicolumn{3}{|c|}{ Methods coherently applied throughout the coaching interaction: systematic approach } \\
\hline $\begin{array}{l}\text { Baseline assessment } \\
\text { Non-equivalent group design } \\
\text { Post-test assessment }\end{array}$ & $\begin{array}{l}\text { pre-test of participants' ability to reflect on their } \\
\text { actions treatment group and control groups.to assess } \\
\text { effect size }\end{array}$ & $\begin{array}{l}\text { Nansubuga et al. [53], } \\
\text { Vidal-Salazar et al. [56] }\end{array}$ \\
\hline $\begin{array}{l}\text { Within-subjects (pre/post) design } \\
\text { with measures taken at Time } 1 \text { and } \\
\text { Time } 2 \text { (four months later). }\end{array}$ & $\begin{array}{l}\text { use both quantitative and qualitative measures to } \\
\text { explore the impact of executive coaching }\end{array}$ & Grant [55] \\
\hline Survey & $\begin{array}{l}\text { prior to coaching, during coaching, and post-coaching. } \\
\text { Data processing: repeated measures analysis }\end{array}$ & Jones et al. [58] \\
\hline $\begin{array}{l}\text { Ongoing feedback One-to-one } \\
\text { interviews }\end{array}$ & $\begin{array}{l}\text { in the course of coaching interaction with participants } \\
\text { at the conclusion of the program }\end{array}$ & Boak and Crabbe [59] \\
\hline
\end{tabular}

The framework indicates that quantitative assessment prevails. This finding is in line with the view of a number of scholars [42], who believe that quantitative methods provide a more objective assessment of coaching outcomes, thereby reducing the risk of subjectivity.

From the design perspective, the studies, which utilize the systematic approach to evaluation, deserve special attention. Scholars and practitioners recognize that a structured and systematized way of assessing the impact of coaching substantially increases the reliability of estimates. Pollitt [62] claims that new standards of coaching also require a system of measuring coaching outcomes to make sure that they truly facilitated achieving business goals.

Among assessment methods presented in the framework, there are methods traditionally applied in the other disciplines, such as psychology, psychotherapy, marketing, etc. The reason for this is that the interest in coaching is steadily increasing, more and more specialists from the other professions are involved in coaching practice. These professionals transfer knowledge gained in the original disciplines to coaching [63]. Thereby, coaching is enriched by the methods for assessing the impact of coaching utilized in the neighboring disciplines. 


\subsection{Coaching and Open Innovation}

To answer research question 3, six available scientific articles were selected as a result of the literature search. The following articles were selected: Almeida, F.L., Oliveira, J.M., Cruz, J.M. [64], Farrukh, C., Athanassopoulou, N., Ilevbare, I. [65], Du Chatenier, E., Verstegen, J.A., Biemans, H.J., Mulder, M., Omta, O. [66], Hahn, C.H., Albers, A., Stoeckner, M., Niever, M., Walter, B., Kerres, R., and Bursac, N. [67], Surya, B.; Menne, F.; Sabhan, H.; Suriani, S.; Abubakar, H.; Idris, M. [68], Yunus, Y.M., Aman, A., Keliwon, K.B. [69].

The search on open innovation and coaching demonstrated that the literature on exploring the interrelation between these two concepts is limited. The analysis of the selected articles enabled us to identify the themes which covered the relationship between open innovation and coaching.

Theme 1. Coaching increases the resilience of the business, thereby facilitating the development of an external knowledge network to foster open innovation.

The authors (Surya et al. [68]) cover the ways of enhancing the productivity of SMEs to increase sustainability and improve marketing. They highlight the role of open innovation in this process and suggest that open innovation advances the development of SMEs by promoting a network of relationships between companies and other external agents. In small and medium enterprises, open innovation contributes to the strengthening of the entrepreneurial and knowledge capacities of all parties involved in the innovation process, thus enhancing the resilience of business through learning and experience. Coaching is seen as a vital means of supporting business resilience, leading to fostering open innovation and expanding the knowledge network [68].

The concept of organizational and entrepreneurial resilience and its influence on open innovation is the subject of extensive study in recent scientific publications [70,71]. The scientific literature provides evidence that coaching intervention is explicitly related to the increase in resilience at the individual level [72]. Meanwhile, the scholars in [72] encourage the companies to use coaching as support for significant change initiatives to enhance resilience not only at the individual level but at the organizational level as well.

Theme 2. Team coaching positively impacts the transfer of knowledge between internal and external stakeholders as well as facilitates the capacity development of innovation teams, which is essential in the context of constantly changing demands and the rapid development of new technologies.

The study conducted by Farrukh, Athanassopoulou and Ilevbare [65] (2019) focuses on university-industry collaboration, discusses how to improve the innovative activity of SMEs and how to make the process of knowledge transfer more effective. The authors believe that inbound open innovation accelerates knowledge transfer and fosters internal innovation within a company. The study explores the impact of team coaching on the transformation of knowledge from universities to SMEs. It was argued that the support of sharing knowledge and know-how transfer is mainly adjusted to team coaching rather than group training. Coaching impacts the crucial aspects which influence knowledge transfer, in other words, coaching improves action learning and boosts decision-taking and action-oriented processes [65].

Open innovation remains a promising approach to optimizing internal innovation, this process requires additional competence development due to rapidly changing customer needs and increasing technological capabilities that companies need to adopt [67]. To meet these challenges, a new approach based on the concept of innovation coaching is proposed. Coaching is seen as a facilitating practice to build and sustain the capabilities of the teams for their high performance [67].

The literature on coaching evidenced the role of team coaching to facilitate the team members to initiate and accelerate collaboration and coordination and thereby increase commitment to tasks or activities to be performed [73]. The aim of team coaching is to support team members to structure their work and make decisions to ensure optimal 
achievement of the results through a joint effort of the group. The scholars also argue that team coaching may enhance the innovation capability of the team through fostering innovative behavior. The study conducted by a group of researchers in [74] investigates the relationship between team coaching and innovations in work teams. Research results show that team coaching is positively correlated with team innovation.

Theme 3. Coaching creates favorable conditions for the environment of continuous learning, thereby contributing to the growth of intellectual capital and the implementation of open innovation strategy.

Collaborative knowledge networks link businesses and communities together and are considered a critical factor for open innovation [64]. However, the authors [64] highlight that traditional business models are not conducive to the creation of collaborative networks. To expand collaborative networks and implement open innovation strategy, the organizational models are to be complemented by "a strong vision of the organization's leadership, an entrepreneurial drive and a continuous learning environment" [64]. The authors argue that coaching creates a favorable learning environment by increasing employees' commitment and encouraging individuals and teams to generate innovative ideas and participate in open innovation projects [64].

The challenges of collaborative knowledge creation in open innovation teams were explored in the academic literature [66]. Collaborative knowledge creation is defined as "a specific type of learning, intentional in nature and directed toward delivering a product (knowledge, service, or technology)" [66]. Although collaborative knowledge creation inspires creativity there are challenges that obstruct the process of generating knowledge collectively. The authors (Du Chatenier et al. [66]) propose ways to advance the process to create collaborative knowledge and overcome obstacles. Coaching was identified as one of the options to create a safe learning environment to facilitate open innovation teams. However, it was noted that despite the knowledge about the methods for creating a culture of learning, and about coaching in particular, in practice, these methods rarely target inter-organizational teams established for the purpose of open innovation [66].

Coaching is frequently referred to as the facilitator to adult learning through promoting self-directed learning and encouraging a shift in thinking. Coaching also helps individuals explore opportunities, analyze alternatives, and based on that create a plan of actions to "deal with new realities, particularly in relation to trying out new roles and building new relationships" [75]. A safe learning environment is regarded as an outcome of coaching interaction. This environment is related to the culture where individuals can safely and without risk to be criticized challenge their new ideas and explore alternatives [75].

Theme 4. Coaching helps the company encourage the end-users of innovation to derive full benefits from innovations.

The study of Yunus, Aman and Keliwon [69] is not directly referred to open innovation, however, the communication of the company with the end-users of innovation is a critical stage in the open innovation process, for that very reason this article was selected for the analysis as well. Coaching is identified as a facilitating practice to encourage the end-users to benefit from innovations. Through observation, listening, asking questions, and other relevant techniques, coaching facilitates companies to communicate the benefits of novelty to the end-users and encourages them to make optimal use of the innovation. The scientific literature also confirms that coaching creates an atmosphere of mutual trust and hence increases the effectiveness of communication [6].

\subsection{Open Innovation for the Advancement of Coaching Knowledge}

Competitive advantage for a company is composed of a number of components. According to scientists, the alignment of all components, such as resources, systems, processes and activities of a company, strengthen company's position on the market [76]. In their study, the scholars made the emphasis on the internal resources. However, attracting external resources can considerably improve the competitiveness of a company and provide 
its sustainable development. The integration of external and internal recourses can be achieved by engaging open innovation.

Open innovation overcomes traditional boundaries and attracts ideas generated externally and thereby combines internal and external resources [77]. This enables to bring a fresh perspective to the established processes since open innovation embraces both inbound and outbound views. The combination of outside-in and inside-out innovation adds value for creating new ideas and knowledge. Moreover, bringing together internal and external resources leads to enhanced collaboration and common purpose networking, and thus, improves knowledge sharing.

To achieve knowledge sustainability, along with economic and social, open innovation should be considered within the context of dynamics. There are basically two levels of open innovation dynamics: open innovation micro-dynamics and open innovation macrodynamics [78]. An important aspect highlighted by the scientists is that there are motivators that trigger "a new combination of technology and the market across the boundary of firms", specifically entrepreneurship motivates open innovation micro-dynamics [78]. The issue pertaining to the dynamics of open innovation in small and medium enterprises (SMEs) needs further investigation, once not all innovation activities can be put into practice at each stage of the company life cycle [79]. The scholars also argue for an increased number of quantitative studies to advance insights into the factors which contribute to the dynamic process of open innovation. There is also a necessity to strengthen the research in the dynamics of open innovation by rigorous statistical methods of data collection and analysis [80]. The issues related to the factors which prompt the dynamic of open innovation are taken into consideration in the scientific debates. Notable contributions were made by Appleyard and Chesbrough [81], who investigated the initial motivations which encourage companies to promote open innovation strategy. Exploring open innovation from the perspective of dynamic capabilities provides a deeper understanding of the value and limitations of open innovation [82,83]. In that regard, the scholars raise the issue of the need to ensure proper management of open innovation strategies in an industrial dynamic capabilities perspective [84]. The allocation of open innovation in the industrial dynamics framework enables "to specify the diversity of agents involved, the complementarities among them, and the boundaries of the system investigated" [85]. Recently, the concept of open innovation was expanded to the economic model in the sense that open innovation provides a new basis for sustainable development cooperation between technology and the market or society $[86,87]$.

Open innovation predominantly occurs in industries [77], and it also can be expected that open innovation can be advanced in other fields, namely in coaching. This will result in enhanced multidisciplinary collaboration among coaching practitioners and researchers, companies that invest in coaching, specialists of neighboring disciplines and universities in designing and using the innovative methods and tools. The joint efforts are likely to lead to the creation of new coaching knowledge and, as a consequence, improve the assessment of the impact of coaching.

The involvement of universities in the investigation of coaching creates an open network and makes innovations in this field interactive. Universities play not only an educational role in contemporary society, but they also perform knowledge creation and transfer functions [88]. Engaging universities is especially relevant when the knowledge required is beyond the competence of specialists, as for example coaching specialists in the multilateral assessment of coaching. The impact of coaching on a company's performance covers changes that occurred at individual, group and organizational levels, and thus it requires the assessment of the impact from different perspectives.

Coaching clients, or recipients of coaching, should also be engaged in the exchange of knowledge related to their perception of the impact of coaching on their attitude, behavior and performance. The coaching outcomes are not only associated with the achievement of goal setting but also relate to the enhancement of self-development and self-awareness. Therefore, the involvement of the coaching clients in the process of creating new innovation- 
based methods and tools for the assessment of the impact of coaching certainly expands the boundaries of coaching knowledge.

It is important to highlight that any agent may initiate the elaboration of new methods for assessing coaching outcomes, thereby generating knowledge flows within the network. Moreover, by being involved, the stakeholders benefit from collaborating with other external parties in ideas development and innovation promotion. Companies, as a part of this network, expand their knowledge about the capacities of coaching. This enables them to evaluate the real impact of coaching on a company's performance, and realize that in certain cases it is feasible to combine coaching with other facilitating activities. Collaboration and knowledge sharing between companies, society and universities bring positive changes in a business environment.

Knowledge sharing can positively affect organizational learning and knowledge acquisition. Being the recipients of coaching, participating in the evaluation of coaching interactions, and contributing to the development of new assessment methods, employees experience not only changes in their ways of critical thinking and behavior, but they also feel empowered, and thus the impact of coaching tends to be prolonged.

\section{Conclusions}

This study aimed to enrich the discussion on the contemporary methods and tools used to assess the impact of coaching on the performance of a company as well as to contribute to the creation of knowledge related to the relationship between coaching and open innovation.

The analysis of the relevant scientific literature available in the Scopus and Web of Science databases has resulted in the elaboration of the framework of the methods which are currently used.

In the scientific literature which was selected for the review, the assessment of the impact of coaching on the individual's behavior and performance of a company is considered from different perspectives: the evaluation of the coach's competence; the measuring the achievements of the coaching clients; the assessment of the changes in a company's performance. The methods also differ based on the needs for the assessment whether the process evaluation or the outcome evaluation is required. Assessment methods from the neighboring disciplines increase the reliability of estimation of the impact of coaching.

The article gave particular attention to mutual benefits to be gained from the relationship between coaching and open innovation. Coaching creates an environment that facilitates the development of the innovative capability of a company. On the other hand, open innovation provides an opportunity to engage new stakeholders and thus expand coaching knowledge.

There are certain limitations to this study. The literature search was conducted using the databases Scopus and Web of Science. The search of articles was only in one subject area, namely Business. There was also the risk that some potentially relevant articles could be omitted. Although the small number of articles selected for the review is justified, it was not possible to conduct a meta-analysis.

The main contribution of this study is made by proposing a framework of the methods which are relevant for different purposes for the assessment of the impact of coaching. Knowledge about different assessment methods, acquired through accumulating findings from a range of studies, enables us to form a set of assessment tools that are relevant to the specific situation and the business context in companies as well as providing opportunities for further research. The present paper also highlights the need for engagement of external agents and knowledge sharing in coaching practice and research. This allows us to overcome the traditional way of thinking accepted by coaches, and attract ideas generated externally and thus combine internal and external resources. Moreover, bringing together internal and external resources leads to enhanced collaboration and networking among coaches, coaching clients, companies, and researchers. 
Author Contributions: Conceptualization, A.R. and N.L.; Investigation, A.R. and N.L.; Methodology, A.R. and N.L.; Supervision, N.L.; Writing-Original Draft, A.R. All authors have read and agreed to the published version of the manuscript.

Funding: This research was funded by the Department of Corporate Finance and Economics, Riga Technical University, Latvia. The APC was funded by the Department of Corporate Finance and Economics, Riga Technical University, Latvia.

Institutional Review Board Statement: Not applicable.

Informed Consent Statement: Not applicable.

Conflicts of Interest: The authors declare no conflict of interest.

\section{References}

1. Engelsberger, A.; Halvorsen, B.; Cavanagh, J.; Bartram, T. Human resources management and open innovation: The role of open innovation mindset. Asia. Pac. J. Hum. Resour. 2021. [CrossRef]

2. Yusr, M.M. Innovation Capability and Its Role in Enhancing the Relationship between TQM Practices and Innovation Performance. J. Open Innov. Technol. Mark. Complex. 2016, 2, 6. [CrossRef]

3. Cho, H.; Lee, P.; Shin, C.H. Becoming a Sustainable Organization: Focusing on Process, Administrative Innovation and Human Resource Practices. Sustainability 2019, 11, 3554. [CrossRef]

4. Wenson, J.E. After-coaching leadership skills and their impact on direct reports: Recommendations for organizations. Hum. Resour. Dev. Int. 2010, 13, 607-616. [CrossRef]

5. Rekalde, I.; Landeta, J.; Albizu, E.; Fernandez-Ferrin, P. Is executive coaching more effective than other management training and development methods? Manag. Decis. 2017, 55, 2149-2162. [CrossRef]

6. de Haan, E. A systematic review of qualitative studies in workplace and executive coaching: The emergence of a body of research. Consult. Psychol. J. 2019, 71, 227-248. [CrossRef]

7. Bozer, G.; Jones, R.J. Understanding the factors that determine workplace coaching effectiveness: A systematic literature review. Eur. J. Work. Organ. Psychol. 2018, 27, 342-361. [CrossRef]

8. McGovern, J.; Lindemann, M.; Vergara, M.; Murphy, S.; Barker, L.; Warrenfeltz, R. Maximizing the impact of executive coaching: Behavioral change, organizational outcomes, and return on investment. Manch. Rev. 2001, 6, 1-9.

9. Bozer, G.; Sarros, J.; Santora, J. The role of coachee characteristics in executive coaching for effective sustainability. J. Manag. Dev. 2013, 32, 277-294. [CrossRef]

10. Cox, E. Coaching Understood. A Pragmatic Inquiry into the Coaching Process; Sage Publications Ltd.: London, UK, 2013.

11. McCarthy, G. Coaching and Mentoring for Business; Sage Publications Ltd.: London, UK, 2014.

12. Audet, J.; Couteret, P. Coaching the entrepreneur: Features and success factors. J. Small Bus. Enterp. Dev. 2012, 19, 515-531. [CrossRef]

13. Hossain, M.; Kauranen, I. Open innovation in SMEs: A systematic literature review. J. Strategy Manag. 2016, 9, 58-73. [CrossRef]

14. Parida, V.; Westerberg, M.; Frishammar, J. Inbound Open Innovation Activities in High-Tech SMEs: The Impact on Innovation Performance. J. Small Bus. Manag. 2012, 50, 283-309. [CrossRef]

15. Chesbrough, H.W. Open Innovation: A New Paradigm for Understanding Industrial Innovation; Oxford University Press: Oxford, UK, 2006.

16. Yun, J.J.; Won, D.; Park, K. Dynamics from open innovation to evolutionary change. J. Open Innov. 2016, 2, 7. [CrossRef]

17. Whittington, R.; Cailluet, L.; Yakis-Douglas, B. Opening Strategy: Evolution of a Precarious Profession. Br. J. Manag. 2011, 22, 531-544. [CrossRef]

18. Gassmann, O.; Enkel, E.; Chesbrough, H. The future of open innovation. $R$ D Manag. 2010, 40, 213-221. [CrossRef]

19. Berkhout, G.; Hartmann, D.; Trott, P. Connecting technological capabilities with market needs using a cyclic innovation model. $R$ D Manag. 2010, 40, 474-490. [CrossRef]

20. Edelbroek, R.; Peters, P.; Blomme, R.J. Engaging in open innovation: The mediating role of work engagement in the relationship between transformational and transactional leadership and the quality of the open innovation process as perceived by employees. J. Gen. Manag. 2019, 45, 5-17. [CrossRef]

21. Barrett, G.; Dooley, L.; Bogue, J. Open innovation within high-tech SMEs: A study of the entrepreneurial founder's influence on open innovation practices. Technovation 2021, 103, 102232. [CrossRef]

22. Prajogo, G.; Ahmed, P. Relationships between innovation stimulus, innovation capacity, and innovation performance. $R D$ Manag. 2006, 36, 499-515. [CrossRef]

23. Gomezel, A.S.; Rangus, K. An exploration of an entrepreneur's open innovation mindset in an emerging country. Manag. Decis. 2018, 56, 1869-1882. [CrossRef]

24. Urze, P.; Rosas, J.; Tenera, A.; Camarinha-Matos, L. Open Innovation Practitioners Mindset on Risk. In Proceedings of the Collaborative Networks and Digital Transformation, PRO-VE 2019, Turin, Italy, 23-25 September 2019; Volume 568, pp. 103-114.

25. Mäkimattila, M.; Melkas, H.; Uotila, T. Dynamics of Openness in Innovation Processes-A Case Study in the Finnish Food Industry. Know. Process Mgmt. 2013, 20, 243-255. [CrossRef] 
26. Nicolopoulou, K.; Karataş-Özkan, M.; Vas, C.; Nouman, M. An incubation perspective on social innovation: The London Hub-A social incubator. $R$ D Manag. 2017, 47, 368-384. [CrossRef]

27. Fichter, K. Innovation communities: The role of networks of promotors in Open Innovation. $R$ D Manag. 2009, 39, 357-371. [CrossRef]

28. Bel, R. Leadership and innovation: Learning from the best. Glob. Bus. Org. Exc. 2010, 29, 47-60. [CrossRef]

29. Bianchi, C.; Steele, M. Coaching for Innovation; Palgrave Macmillan: London, UK, 2014.

30. Becker, B.; Gassmann, O. Gaining leverage effects from knowledge modes within corporate incubators. R D Manag. 2006, 36, 1-16. [CrossRef]

31. O'Connor, G.C.; DeMartino, R. Organizing for Radical Innovation: An Exploratory Study of the Structural Aspects of RI Management Systems in Large Established Firms. J. Prod. Innov. Manag. 2006, 23, 475-497. [CrossRef]

32. Lam, L.; Nguyen, P.; Le, N.; Tran, K. The Relation among Organizational Culture, Knowledge Management, and Innovation Capability: Its Implication for Open Innovation. J. Open Innov. Technol. Mark. Complex. 2021, 7, 66. [CrossRef]

33. Beretta, M.; Björk, J.; Magnusson, M. Moderating Ideation in Web-Enabled Ideation Systems. J. Prod. Innov. Manag. 2018, 35, 389-409. [CrossRef]

34. Hidalgo, A.; Albors, J. Innovation management techniques and tools: A review from theory and practice. $R$ D Manag. 2008, 38, 113-127. [CrossRef]

35. Gilley, A.; Gilley, J.W.; McMillan, H.S. Organizational Change: Motivation, Communication, and Leadership Effectiveness. Perf. Improv. Qrtly. 2009, 21, 75-94. [CrossRef]

36. Moellers, T.; Visini, C.; Haldimann, M. Complementing open innovation in multi-business firms: Practices for promoting knowledge flows across internal units. $R$ D Manag. 2020, 50, 96-115. [CrossRef]

37. Badir, Y.F.; Frank, B.; Bogers, M. Employee-level open innovation in emerging markets: Linking internal, external, and managerial resources. J. Acad. Mark. Sci. 2020, 48, 891-913. [CrossRef]

38. Shipton, H.; Sparrow, P.; Budhwar, P.; Brown, A. HRM and innovation: Looking across levels. Hum. Resour. Manag. J. 2017, 27, 246-263. [CrossRef]

39. Frattini, F.; De Massis, A.; Chiesa, V.; Cassia, L.; Campopiano, G. Bringing to Market Technological Innovation: What Distinguishes Success from Failure. Int. J. Eng. Bus. 2012, 4, 4-15. [CrossRef]

40. West, J.; Bogers, M. Leveraging External Sources of Innovation. J. Prod. Innov. Manag. 2014, 31, 814-831. [CrossRef]

41. Gassmann, O.; Daiber, M.; Enkel, E. The role of intermediaries. R D Manag. 2011, 41, 457-469. [CrossRef]

42. Lawrence, P.; Whyte, A. Return on investment in executive coaching: A practical model for measuring ROI in organisations. Coach. Int. J. Theory Res. Pract. 2014, 7, 4-17. [CrossRef]

43. de Meuse, K.; Dai, G.; Lee, R. Evaluating the effectiveness of executive coaching: Beyond ROI? Coach. Int. J. Theory Res. Pract. 2009, 2, 117-134. [CrossRef]

44. Passmore, J.; Fillery-Travis, A. A critical review of executive coaching research: A decade of progress and what's to come. Coach Int. J. Theory Res. Pract 2011, 4, 70-88. [CrossRef]

45. Grant, A. Solution-Focused Coaching. In Excellence in Coaching: The Industry Guide; Passmore, J., Ed.; Kogan Page: London, UK, 2006; pp. 73-90.

46. Greif, S. Advances in research on coaching outcomes. Int. Coach. Psychol. Rev. 2007, 2, 222-245.

47. Bachkirova, T.; Sibley, J.; Myers, A. Developing and Applying a New Instrument for Microanalysis of the Coaching Process: The Coaching Process Q-Set. Hum. Resour. Dev. Q. 2015, 26, 431-462. [CrossRef]

48. Birknerová, Z.; Benková, E. The assessment of coaching by trade managers. Pol. J. Manag. Stud. 2020, 22, 74-85. [CrossRef]

49. Albizu, E.; Rekaldee, I.; Landeta, J.; Fernández-Ferrín, P. Analysis of executive coaching effectiveness: A study from the coachee perspective. Cuad. De Gest. 2019, 19, 33-52. [CrossRef]

50. Wenu, A.; Tan, C. The applied, knowledge, and work-based oriented project management coaching framework (AKW-PMCF). J. Mod. Proj. Manag. 2019, 6, 28-45.

51. Pousa, C.; Hardie, T.; Zhang, X. Promoting frontline employee customer orientation in China: A replication and a comparison. Int. J. Bank Mark. 2018, 36, 849-867. [CrossRef]

52. Hagen, M.S.; Peterson, S.L. Measuring coaching: Behavioral and skill-based managerial coaching scales. J. Manag. Dev. 2015, 34, 114-133. [CrossRef]

53. Nansubuga, F.; Munene, J.C.; Ntayi, J.M. Can reflection boost competences development in organizations? Eur. J. Train. Dev. 2015, 39, 504-521. [CrossRef]

54. Gan, G.C.; Chong, C.W. Coaching relationship in executive coaching: A Malaysian study. J. Manag. Dev. 2015, 34, 476-493. [CrossRef]

55. Grant, A.M. The Efficacy of Executive Coaching in Times of Organisational Change. J. Chang. Manag. 2014, 14, 258-280. [CrossRef]

56. Vidal-Salazar, M.D.; Ferrón-Vílchez, V.; Cordón-Pozo, E. Coaching: An effective practice for business competitiveness. Compet. Rev. 2012, 22, 423-433.

57. Gray, D.E.; Ekinci, Y.; Goregaokar, H. Coaching SME managers: Business development or personal therapy? A mixed method study. Hum. Resour. Manag. J. 2012, 22, 863-882. [CrossRef]

58. Jones, R.A.; Rafferty, A.E.; Griffin, M.A. The executive coaching trend: Towards more flexible executives. Leadersh. Organ. Dev. J. 2006, 27, 583-595. [CrossRef] 
59. Boak, G.; Crabbe, S. Evaluating the impact of coaching skills training on individual and corporate behaviour. Eur. J. Train. Dev. 2018, 43, 135-165. [CrossRef]

60. Nguyen, C.; Artis, A.; Plank, R.; Solomon, P. Dimensions of effective sales coaching: Scale development and validation. J. Pers. Sell. Sales Manag. 2019, 39, 299-315. [CrossRef]

61. Bozer, G.; Jones, R.J. Introduction to the Special Issue on Advances in the Psychology of Workplace Coaching. Appl. Psychol. Int. Rev. 2021, 70, 411-419. [CrossRef]

62. Pollitt, D. Financial-services company drives out coaching inefficiencies: Now all suppliers are suited to today's fast-pace, high-change environment. Hum. Resour. Manag. Int. Dig. 2013, 21, $26-27$.

63. Cox, E.; Bachkirova, T.; Clutterbuck, D. (Eds.) The Complete Handbook of Coaching; Sage Publications Ltd.: London, UK, 2010.

64. Almeida, F.L.; Oliveira, J.M.; Cruz, J.M. Paths to Accomplish a Successful Open Innovation 2.0 Strategy. Int. J. Innov. Sci. 2009, 1, 131-140. [CrossRef]

65. Farrukh, C.; Athanassopoulou, N.; Ilevbare, I. How Inbound Open Innovation Helps SMEs Learn and Improve: Knowledge Transfer from University to Industry through Direct Coaching. 2019. Available online: https://www.repository.cam.ac.uk/ handle/1810/288409 (accessed on 10 November 2021).

66. Du Chatenier, E.; Verstegen, J.A.; Biemans, H.J.; Mulder, M.; Omta, O. The challenges of collaborative knowledge creation in open innovation teams. Hum. Resour. Dev. Rev. 2009, 8, 350-381. [CrossRef]

67. Hahn, C.H.; Albers, A.; Stoeckner, M.; Niever, M.; Walter, B.; Kerres, R.; Bursac, N. Innovation Coaching in Foresight Processes for Distributed Product Development. Proc. Collab. Eur. Res. Conf. 2017, 1, 366-375.

68. Surya, B.; Menne, F.; Sabhan, H.; Suriani, S.; Abubakar, H.; Idris, M. Economic Growth, Increasing Productivity of SMEs, and Open Innovation. J. Open Innov. Technol. Mark. Complex. 2021, 7, 20. [CrossRef]

69. Yunus, Y.M.; Aman, A.; Keliwon, K.B. The Role of Business Leaders in Information Technology Innovation in the New Era of Disruptive Technology. Asian J. Account. Gov. 2019, 12, 133-142.

70. Santoro, G.; Bertoldi, B.; Giachino, C.; Candelo, E. Exploring the relationship between entrepreneurial resilience and success: The moderating role of stakeholders' engagement. J. Bus. Res. 2020, 119, 142-150. [CrossRef]

71. Lengnick-Hall, C.A.; Beck, T.E.; Lengnick-Hall, M.L. Developing a capacity for organizational resilience through strategic human resource management. Hum. Resour. Manag. Rev. 2011, 21, 243-255. [CrossRef]

72. Grant, A.M.; Curtayne, L.; Burton, G. Executive coaching enhances goal attainment, resilience and workplace well-being: A randomised controlled study. J. Posit. Psychol. 2009, 4, 396-407. [CrossRef]

73. Hackman, J.; Wageman, R. A theory of team coaching. Acad. Manag. Rev. 2005, 30, 269-287. [CrossRef]

74. Rousseau, V.; Aubé, C.; Tremblay, S. Team coaching and innovation in work teams. Leadersh. Organ. Dev. 2013, 34, 344-364. [CrossRef]

75. Cox, E. Coaching and Adult Learning: Theory and Practice. New Dir. Adult Cont Educ. 2015, 148, 27-38. [CrossRef]

76. Orjuela, A.; Andrade, J.M.; Cardona, E.A.; Peralta, R.; Mendez, J.J. Methodological proposal for the identification of incremental innovations in SMEs. Eur. Res. Stud. 2019, 22, 199-214. [CrossRef]

77. Yun, J.J.; Liu, Z. Micro- and Macro-Dynamics of Open Innovation with a Quadruple-Helix Model. Sustainability 2019, 11, 3301. [CrossRef]

78. Yun, J.J.; Zhao, X.; Jung, K.; Yigitcanlar, T. The Culture for Open Innovation Dynamics. Sustainability 2020, 12, 5076. [CrossRef]

79. Van de Vrande, V.J.A.; De Jong, J.P.J.; Vanhaverbeke, W.P.M.; De Rochemont, M.H. Open innovation in SMEs: Trends, motives and management challenges. Technovation 2009, 29, 423-437. [CrossRef]

80. Yun, J.J.; Park, K.; Im, C.; Shin, C.; Zhao, X. Dynamics of Social Enterprises-Shift from Social Innovation to Open Innovation. Sci. Technol. Soc. 2017, 22, 425-439. [CrossRef]

81. Appleyard, M.M.; Chesbrough, H.W. The Dynamics of Open Strategy: From Adoption to Reversion. Long Range Plan. 2017, 50, 310-321. [CrossRef]

82. Bogers, M.; Chesbrough, H.; Heaton, S.; Teece, D.J. Strategic Management of Open Innovation: A Dynamic Capabilities Perspective. Calif. Manage. Rev. 2019, 62,77-95. [CrossRef]

83. Milici, A.; Ferreira, F.; Pereira, L.; Carayannis, E.; Ferreira, J. Dynamics of open innovation in small- and medium-sized enterprises: A metacognitive approach. IEEE Trans. Eng. Manag. 2021, 1-14. [CrossRef]

84. Kolk, A.; Puumann, K. Co-Development of Open Innovation Strategy and Dynamic Capabilities as a Source of Corporate Growth. Work. Pap. Econ. TUTWEP 2008, 173, 73-83.

85. Christensen, J.F.; Olesen, M.H.; Kjær, J.S. The industrial dynamics of Open Innovation-Evidence from the transformation of consumer electronics. Res. Policy 2005, 34, 1533-1549. [CrossRef]

86. Yun, J.H.J.; Won, D.K.; Park, K.B. Entrepreneurial cyclical dynamics of open innovation. J. Evol. Econ. 2018, 28, 1151-1174. [CrossRef]

87. Rayna, T.; Striukova, L. Open social innovation dynamics and impact: Exploratory study of a fab lab network. $R$ D Manag. 2019, 49, 383-395. [CrossRef]

88. Poyago-Theotoky, J.; Beath, J.; Siegel, D.S. Universities and fundamental research: Reflections on the growth of university-industry partnerships. Oxf. Rev. Econ. Policy 2002, 18, 10-21. [CrossRef] 